\title{
HOW DO THE "GATS-PLUS" AND "GATS-MINUS" CHARACTERISTICS OF REGIONAL SERVICE AGREEMENTS AFFECT TRADE IN SERVICES?
}

\author{
Nianli Zhou \\ John Whalley \\ Working Paper 20551 \\ http://www.nber.org/papers/w20551
NATIONAL BUREAU OF ECONOMIC RESEARCH
1050 Massachusetts Avenue
Cambridge, MA 02138
October 2014

We are grateful to the Ontario Research Fund and National Social Science Fund of China (13CGJ031) for support. The views expressed herein are those of the authors and do not necessarily reflect the views of the National Bureau of Economic Research.

NBER working papers are circulated for discussion and comment purposes. They have not been peerreviewed or been subject to the review by the NBER Board of Directors that accompanies official NBER publications.

(C) 2014 by Nianli Zhou and John Whalley. All rights reserved. Short sections of text, not to exceed two paragraphs, may be quoted without explicit permission provided that full credit, including $\odot$ notice, is given to the source. 
How Do the "GATS-Plus" and "GATS-Minus" Characteristics of Regional Service Agreements Affect Trade in Services?

Nianli Zhou and John Whalley

NBER Working Paper No. 20551

October 2014

JEL No. F13,F15

\begin{abstract}
Preferential liberalization of trade in services is a central feature of the new regionalism. "GATS-Plus" and "GATS-Minus" have become the distinctive characteristics of the service RTAs and this paper aims to investigate and distinguish the different effect of the "GATS-Plus" and "GATS-Minus" components of RTAs on the service trade . The results of the empirical research by using the gravity equation either with time-varying exporter and importer fixed effects or with the specific exporter and importer fixed effect and year fixed effect both indicate : (1) belonging to a RTA (both "only goods" RTA and "service" RTA) can increase the bilateral service trade between the trading-pairs significantly. (2) almost all the "GATS-plus" and "GATS-neutral" commitments either on market access or on national treatment made by trading-pairs with each other under service RTAs have significantly positive effect on bilateral service export. (3) the commitments of "GATS-minus" characteristic do not have significant negative effects on bilateral service export because "GATS-minus" treatment can be neutralized to some extent by two main preferential erosion mechanisms under the RTAs: "liberal rule of origin" and "non-party MFN provision".
\end{abstract}

Nianli Zhou

China Institute for WTO Studies

University of International Business and Economics

Beijing, PRC, 100029

znluibe@163.com

John Whalley

Department of Economics

Social Science Centre

University of Western Ontario

London, ON N6A 5C2

CANADA

and NBER

jwhalley@uwo.ca 


\section{How Do the "GATS-Plus" and "GATS-Minus" Characteristics of Regional Service Agreements Affect Trade in Services?}

\section{Introduction}

\subsection{Raise the Issue}

Due to technological progress, the trend towards privatization and the liberalization of capital flows, a wide range of service activities that were previously considered nontradable now enter international commerce. In the last three decades, services account for the fastest growing segment of international trade. The volume of world trade in services increased more than 11-fold from US\$387 billion in 1980 to US\$4,350 billion in 2012. As a consequence, international trade negotiations have increasingly considered services. From being a marginal phenomenon before 2000, preferential liberalization of trade in services has now become a central feature of trade negotiation which can be regarded as the part of the "deep" behind the border commitments that characterize the new regionalism. According to the WTO database, 133 RTAs covering services have been notified under GATS Article V at the end of January 2014, of which 118 RTAs were in force. So far the key traditional demanders in multilateral services negotiations such as United States, EU, Japan, Canada, Australia and the major developing economies including China, Chile, Mexico, India etc have all taken an active part in the regional service liberalization process. Governments that are parties to these regional service agreements account for more than $80 \%$ of world services trade (Roy et.al, 2006). Given the rising popularity of RTAs on services, their impact on services flows becomes a concern. Though one might expect that countries entering these RTAs do so with the objective of eliminating barriers to trade in services and in the hope that the agreements will increase the services trade between the parties, the real consequence is an empirical issue.

\subsection{Literature Review}

Economic literature is replete with theoretical models and empirical analyses documenting the impact of RTAs on trade between partner countries. But most of the existing studies have focused only on goods. Due to the scarcity of the reliable data on 
trade in services, especially of bilateral flows, it is almost impossible to carry out empirical research on the bilateral trade patterns for services- in particular - on the RTA's effects on trade flows in services. Fortunately, to some extent, this lacuna has been filled with the publication of the OECD's database on bilateral services trade in 2002 (Shingal, 2010). Since then more attention has been given to the role of RTAs on trade in services. In sum, two distinct empirical methods have been employed in investigating this problem: Computable General Equilibrium (CGE) models and Gravity Model. Because the CGE model sets a high requirement on data, the utilization of it in this field is difficult and limited. In comparison, the gravity model as one of the most successful empirical tools in economics which can relate service trade flows between countries to their geographic and economic characteristics easily has become the mainstream method to explain the determinants of bilateral service trade.

It should be noted that though most original literature on the determinants of services include a binary variable RTA indicating whether the trading countries are in a regional trading agreement in the gravity equation, chances are that the variable RTA is treated more as a control rather than a policy variable of interest and the significance of its influence on service trade volume tends to differ across studies. Grünfeld and Moxnes (2003) separated total services into travel, transport, government and commercial services and applied a gravity model to the bilateral export of services and FDI flows based on data for 1999 from the OECD. The paper included a dummy variable for common RTA membership, a measure of corruption and a trade restrictiveness index of the importing country as the regressors. Their results indicated a common membership in a regional free trade agreement has no significant effect on service trade which reflects the fact that many RTAs do not emphasize the liberalization of service trade and strong impediments to service trade still exist through national regulations.

Like Grünfeld and Moxnes (2003), Walsh (2006) also used a gravity equation to estimate the determinants of total services, government services, transport services, travel and other commercial services separately based on the import data for 27 OECD countries in three-year period (1999-2001). In order to reduce the heterogeneity bias of the random effect and the time-variant variables omission bias of the fixed-effects model, Walsh used the Hausman-Taylor model for the first time .Walsh's results suggested that 
GDP per capita and a common language can be the most important determinants of bilateral service trade, but the adjacency and membership of the European Union did not increase services trade significantly, which confirms the result of Grünfeld and Moxnes (2003).

Concerning RTAs' effect on the service trade, other literature contradicted the argument given above. Gilbert et.al. (2001) investigated the effects of specific regional trading arrangements on bilateral services trade based on a sample of 38 countries for 1997. They found evidence of significant effects from the standard gravity variables of economic size and distance and trade-enhancing effects of a limited number of specific RTAs. Kimura and Lee (2006) extended the standard gravity framework by including a measure of remoteness (a trade weighted measure of the distance between the two countries) and a measure of trade restrictiveness (the Economic Freedom of the World Index developed by the Fraser Institute) as regressors. By estimating this extended gravity equation with a mixture of ordinary least-squares (OLS) and time-fixed effects and based on the OECD statistics on trade in services for the years 1999 and 2000, their results suggested RTAs can have significant positive effects on trade in services and even under the conditions that RTAs did not explicitly cover services. The presence of the "Only goods" RTAs could indirectly facilitate the process of service trade, which is contrary to that of Grünfeld and Moxnes (2003). Mirza and Nicoletti (2004) formulated and tested a gravity model of services exports by using the data from the OECD with an emphasis on the unique characteristics of services trade. Their results confirmed the roles of economic size and distance in services exports and reported a large significant effect of membership in a common RTA on bilateral services exports. Ceglowski (2006) estimated a gravity equation for services trade based on a sample of 28 OECD countries for the period 1999-2000. Her study used a dummy variable for the membership in a group of RTAs including CER between Australia and New Zealand, the EFTA, the EU, NAFTA and the European Economic Area. The study found the common membership in a RTA has a significant, positive effect on bilateral services trade and much of that effect appears to reflect the impact of bilateral trade in goods on services trade. The policy implication of this result is that service export can be promoted through the RTAs by raising member’s bilateral goods trade. 
In recent years because of the acceleration of the regional service trade liberalization process, some economies especially the developing ones begin to wonder how to design their regulations and make commitments under the framework of RTAs and what kinds of RTAs can be used as a tool to enhance their social and economic welfare such as decreasing the deficit of service trade. The heterogeneity of the RTAs and their different effects on service trade has aroused a wide attention. The variables describe the characteristic of RTAs become the key explanatory variables of policy interest in the gravity model. The following are the representative literatures.

Shingal (2010) used the gravity model to distill the trade effects of RTAs on bilateral services trade into those emanating from services RTA and "only goods" agreements and thereby confirming complementarities between the two. Depending on the economic status of the two trading partners, this research classified the RTA as North-North (NN), South-South (SS) and North-South (NS). It further broke down NS-RTA into symmetric and asymmetric depending on the extent of reciprocity of commitments and their implementation between the partner countries. Their results indicated that in addition to a services RTA, the incremental impact of an "only goods" RTA is also important for the sample. North-South services agreements are found to be more conducive to raising bilateral services exports between trading partners and this trade effect emanates largely from asymmetric North-South agreements.

Park and Park (2010) applied the gravity regression analysis to four major services sectors(financial, business, communication and transportation services) and found service RTAs can create service trade inside the region but the trade-enhancing effect is sectorspecific. The trade enhancing effect of RTAs is stronger between the developed members than that between the developed and developing countries. The author also examined whether the trade effects of RTAs vary over time.

Guillin (2013) firstly took the liberalization "depth” of the service RTAs into account. According to the degree of liberalization in service trade, this paper divided the RTAs into several categories and estimated the trade effect of each category by using the gravity equation which included the bilateral and country-and-time fixed effects. Basing on the panel data from 1999 to 2007, their results showed that only EIAs (RTAs which covered the service trade) have a positive and significant impact on trade in services. 
Moreover, as expected, the deeper the agreement is, the more intra-trade the signatory countries have.

Behncke (2013) analyzed the relationship between intra EU trade in services and European Integration based on a panel data set covering the year period of 2000-2010. The author paid much attention to overcoming the endogenous bias of the EU dummy and compared the service trade effect induced from European trade integration and European monetary integration. Her results indicated a high positive impact on aggregate services trade between member states from the former and a negative one from the latter. The positive effect can vary between the service sectors and the more distinctive effects are for business services, travel and EDV services.

\subsection{Contribution of the Paper}

Existing literature analyzing the RTA's effect on service trade using gravity-based approaches shows a lack of consensus. In fact, global service trade liberalization is advancing along two tracks: a multilateral track (GATS and its subsequent negotiation) and a regional track (regional, sub regional and bilateral agreements).Both systems have produced an increasingly complex web of rules, principles and commitments that regulate the service trade flow. By means of a very detailed comparison of the two systems, a typology has been established for classifying specific elements in the RTAs depending on whether they simply mirror GATS provisions (“GATS-neutral”), go beyond GATS provisions ("GATS-Plus”) or fall short of GATS provisions in some respect ("GATSMinus”). Several studies have been conducted to compare RTAs and GATS including Sauvé (2005) who pointed out the key architectural innovations of services RTAs. Stephenson (2005) and Roy et al. (2006) evaluate the liberalization content of selected bilateral and regional agreements. Marconini (2006), Goncalves and Stephanou (2007) review the negotiating experiences of countries in Latin America and the Caribbean. But when it comes to the empirical research on the service trade effect of the RTAs, the existing literature has not paid attention to the "GATS-Plus", "GATS-neutral” and "GATS-Minus" characteristics of the RTAs and has not distinguished the possible different effects of these characteristics on the service trade. This paper tries to make a contribution at the empirical level by investigating and distinguishing the different effect of the "GATS-Plus" and "GATS-Minus” component of RTAs on the service trade based 
on the gravity model. This research can help shed light on the following questions: What types of the service commitment (“GATS-Plus” or "GATS-Minus”) under the RTAs appear to encourage bilateral service trade? Will the "GATS-Plus” commitment promote service trade significantly and why? Will the "GATS-Minus" commitment yield an adverse effect as general expected and why?

The paper is structured as follows. Section 2 gives a brief but comprehensive introduction to the "GATS-Plus" and "GATS-Minus" characteristic of RTAs from the perspective of commitment and architecture. Section 3 is the empirical research (specifying model, sample, data and relevant estimation techniques). Section 4 summarizes the empirical findings and gives the policy implication .Section 5 concludes this research.

\section{2、 “GATS-Plus" and "GATS-Minus" characteristic of the Regional Service Agreements}

\section{1 “GATS-Plus” and “GATS-Minus” Commitments and Their Distribution}

Regional Service Agreements can produce the so called "GATS-Plus” commitment in two main ways.The first is to assure partners' service provider that they can be regarded as the local service providers on issues such as regulation and taxation. This commitment can extend the national treatment (NT) to areas where the nation has not made such commitment in the GATS yet. The second is to provide better market access (MA) to the partner's service providers (such as recognition of professional qualifications for

individuals and regulatory certification for firms etc) (Baldwin et.al, 2007). In general, the main performance of the "preferential content" under the framework of the Regional Service Agreements can be the "wider" or "deeper" commitment concerning market access or national treatment compared with that of GATS.

Several literatures have tried to assess the "GATS-Plus" commitments in the Regional Service Agreements. The representative literatures are as follows. Roy et.al (2006) reviewed the commitments undertaken by 29 WTO Members (counting the EC as one) under mode 1 and 3 in 28 PTAs negotiated since 2000 and compared them with these members' GATS commitment and Doha Round offers. To assess the RTA commitments, the research focus both on "the sector coverage" and on "the commitment depth" in order 
to provide an aggregate picture on to what extent the members of the RTAs have undertaken new commitments or improved the level of bindings for already committed sectors. Roy (2011) and Fink and Molinuevo(2007) followed the same method of Roy et.al (2006).The difference lies in Roy ( 2011 ) extended the sample of Roy et.al (2006)’s database to cover 53 WTO Members (also counting EU Members States as one). Like its earlier version, the expanded dataset limited its assessment to mode 1 and 3 because both modes represent the overwhelming share of total world services trade. On the contrary, Fink and Molinuevo (2007) also took the other two modes (mode 2 and 4) into account, but their analysis is just based on 25 FTAs which participated by at least one East Asian country. As far as we know, Miroudot et.al (2010) gave a more comprehensive and detailed measurement on the "value-added" of RTAs. Based on 56 regional trade agreements where an OECD country is a party, the preferential content of RTAs was assessed for each sub-sector (155 sub-sectors in total based on GATS Sectoral Classification List), each mode of supply (four mode) and each type of commitment (market access or national treatment). Based on Miroudot et.al (2010), this paper calculates the "Preference Margin” ("PM" is used to signify the ratio of the subsectors on which the member has made the GATS-Plus commitment for the service provider from the RTAs partner) of these RTAs for each mode (table 1) and each sector (table 2).

\section{TABLE 1}

RTAs VS GATS: Modal difference in liberalization level and Preference Margin

\begin{tabular}{|c|c|c|c|c|c|c|c|c|}
\hline & \multicolumn{4}{|c|}{ Market Access Commitment } & \multicolumn{4}{|c|}{ National Treatment Commitment } \\
\hline & GATS & RTA & GATS/RTA & PM & GATS & RTA & GATS/RTA & PM \\
\hline & $(0-100)$ & $(0-100)$ & $(\%)$ & $(\%)$ & $(0-100)$ & $(0-100)$ & $(\%)$ & $(\%)$ \\
\hline Mode 1 & 25.1 & 66.2 & 37.91 & 62.09 & 26.7 & 67.8 & 39.38 & 60.62 \\
\hline Mode 2 & 33.8 & 73.3 & 46.11 & 53.89 & 33.8 & 74.9 & 45.13 & 54.87 \\
\hline Mode 3 & 36.9 & 75.4 & 48.93 & 51.07 & 43.1 & 77.9 & 55.33 & 44.67 \\
\hline Mode 4 & 20.0 & 75.4 & 26.53 & 73.47 & 19.5 & 71.8 & 27.16 & 72.84 \\
\hline Total & 29.7 & 72.3 & 41.08 & 58.92 & 31.3 & 73.3 & 42.70 & 57.30 \\
\hline
\end{tabular}

Note: (1) The figures in column 2 and 7 (column 3 and 8 ) are obtained by the ratio of the subsector which the member has made commitment on this mode in the GATS (RTAs) multiplied by 100. (2) The figures in column 4 
(column 9) are obtained by the number of the subsectors which the member has made commitment in the GATS divided by the number of subsectors which the member has made commitment in the RTAs. (3) The figures in column 5 (column 10) are obtained by 1 minus the figured in the column 4 (column 9). The index preferential margin (PM) is used to evaluate to what extent the commitment under the RTAs go beyond the GATS.

Source: Author's calculations based on Miroudot et.al (2010).

The results in the Tables 1 and 2 confirm that in general, the commitments under the service RTAs have go beyond that of GATS by introducing preferential bindings in a significant number of new supply mode and new sub-sectors. Specifically, these calculations results indicate: (1) the value of PM for market access and national treatment for the total mode are 58.92 and 57.30(column 5 and 10 of Table 1). This means in close to $60 \%$ subsectors covered by RTAs, the service providers come from the RTAs partner have been given the preferential treatment (so called "GATS-Plus" commitment). (2) The preferential margin of mode 4 is highest (73.47 and 72.84), next is the mode 1(62.09 and 60.62) and mode2 (53.89 and 54.87), mode 3 is the lowest (51.07 and 44.67). (3)From the perspective of the sector, the "GATS-Plus" market access commitment is more concentrated on "Other services” (90.16), “ Health related and social services”(80.28), “ Transport services”(74.7), “Recreational, cultural and sporting services”(70.83), on the other side the value of PM in "Communication service”( 47.62) and "Financial services"(52.33) is comparatively low.

The "value added" of the RTAs generated from broadening the sector(mode) coverage or deepening the liberalization level is distinguished, but the phenomenon of "negative preference” (the commitment of RTAs fall short of the same country' GATS commitments) cannot be ignored either. Based on a review of some 80,000 commitments in 66 agreements, Adlung and Miroudot(2012) listed four representative kinds of “GATS-Minus” commitments- “including additional restrictions not listed in GATS" (additional), “tightening the existing GATS limitations” (tightening), “omission of subsectors or sector segments" (omitted) and "reciprocity elements" (reciprocity) — and provided an overview of modes and service sectors that has been affected by them .Table 3 indicates that GATS-minus commitments can be found in the vast majority of the 66 RTAs. In detail: (1) “GATS-Minus” commitments are concentrated on mode 3(commercial presence) and mode 4(movement of natural persons) and the commitments on $35 \%$ (36\%) subsectors of the mode 3 (mode 4) contained the GATS-minus 
commitments. The corresponding figure for mode 1 (mode 2 ) is $16 \%(13 \%)$. (2) Concerning individual sectors, "financial services” (38\%), “communication services" (24\%) and "business services" (19\%) have been affected by the "GATS-Minus" commitments most, the least affected ones include "Construction and engineering”(2\%), “Education services”(2\%), “Tourism \&travel-related services”(2\%), "Distribution services” (1\%), “Environmental service” (1\%) and “Recreational, cultural, sports services” (1\%).

\section{TABLE 2}

RTAs VS GATS: Sector difference in liberalization level and Preference Margin

\begin{tabular}{|c|c|c|c|c|}
\hline & $\begin{array}{c}\text { GATS } \\
(0-100)\end{array}$ & $\begin{array}{c}\text { RTA } \\
(0-100)\end{array}$ & $\begin{array}{c}\text { GATS/RTA } \\
(\%)\end{array}$ & $\begin{array}{l}\mathrm{PM} \\
(\%)\end{array}$ \\
\hline Business service & 35.56 & 83.7 & 42.48 & 57.52 \\
\hline Communication service & 40.74 & 76.64 & 52.38 & 47.62 \\
\hline $\begin{array}{l}\text { Construction and related } \\
\text { engineering services }\end{array}$ & 37.23 & 77.37 & 48.11 & 51.89 \\
\hline Distribution Services & 25.55 & 83.94 & 30.43 & 69.57 \\
\hline Education services & 26.28 & 73.72 & 35.64 & 64.36 \\
\hline Environmental services & 32.12 & 73.72 & 43.56 & 56.44 \\
\hline Financial services & 29.93 & 62.77 & 47.67 & 52.33 \\
\hline $\begin{array}{c}\text { Health related and social } \\
\text { services }\end{array}$ & 10.22 & 51.82 & 19.72 & 80.28 \\
\hline $\begin{array}{l}\text { Tourism and travel } \\
\text { related services }\end{array}$ & 40.88 & 81.75 & 50.00 & 50.00 \\
\hline $\begin{array}{l}\text { Recreational, cultural } \\
\text { and sporting services }\end{array}$ & 20.44 & 70.07 & 29.17 & 70.83 \\
\hline Transport services & 15.33 & 60.58 & 25.30 & 74.70 \\
\hline Other services & 6.57 & 60.58 & 10.84 & 90.16 \\
\hline
\end{tabular}

Note: (1) The figures in column 2(column 3) are obtained by the ratio of the subsector which the member has made commitment on this mode in the GATS (RTAs) multiplied by 100. (2) The figures in column 4 are obtained by the number of the subsectors which the member has made commitment in the GATS divided by the number of subsectors which the member has made commitment in the RTAs. (3) The figures in column 5 are obtained by 1 minus the figured in the column 4 . The index preferential margin (PM) is used to evaluate to what extent the commitment under the RTAs go beyond the GATS. 
Source: Author's calculations based on Miroudot et.al (2010).

\section{TABLE 3}

GATS-minus Commitments by Mode of Supply and Service Sector

\begin{tabular}{|c|c|c|c|c|c|c|}
\hline & Number & Percentage & Additional & Tightening & Omitted & Reciprocity \\
\hline \multicolumn{7}{|l|}{ By mode of supply } \\
\hline Mode 1 & 483 & $16 \%$ & $45 \%$ & $7 \%$ & $49 \%$ & $1 \%$ \\
\hline Mode 2 & 397 & $13 \%$ & $24 \%$ & $8 \%$ & $68 \%$ & $0 \%$ \\
\hline Mode 3 & 1104 & $35 \%$ & $35 \%$ & $11 \%$ & $59 \%$ & $1 \%$ \\
\hline Mode 4 & 1129 & $36 \%$ & $27 \%$ & $31 \%$ & $49 \%$ & $0 \%$ \\
\hline \multicolumn{7}{|l|}{ By sector } \\
\hline Business services & 594 & $19 \%$ & $43 \%$ & $20 \%$ & $43 \%$ & $2 \%$ \\
\hline Communication services & 760 & $24 \%$ & $43 \%$ & $21 \%$ & $40 \%$ & $0 \%$ \\
\hline $\begin{array}{l}\text { Construction\& } \\
\text { engineering }\end{array}$ & 56 & $2 \%$ & $63 \%$ & $39 \%$ & $18 \%$ & $0 \%$ \\
\hline Distribution services & 39 & $1 \%$ & $33 \%$ & $26 \%$ & $41 \%$ & $0 \%$ \\
\hline Education services & 61 & $2 \%$ & $70 \%$ & $15 \%$ & $21 \%$ & $0 \%$ \\
\hline Environmental service & 40 & $1 \%$ & $50 \%$ & $30 \%$ & $40 \%$ & $0 \%$ \\
\hline Financial services & 1195 & $38 \%$ & $15 \%$ & $10 \%$ & $78 \%$ & $1 \%$ \\
\hline $\begin{array}{l}\text { Health-related \&social } \\
\text { services }\end{array}$ & 17 & $1 \%$ & $41 \%$ & $47 \%$ & $12 \%$ & $0 \%$ \\
\hline $\begin{array}{l}\text { Tourism \&travel-related } \\
\text { services }\end{array}$ & 69 & $2 \%$ & $38 \%$ & $29 \%$ & $42 \%$ & $0 \%$ \\
\hline $\begin{array}{l}\text { Recreational, } \\
\text { cultural ,sports services }\end{array}$ & 34 & $1 \%$ & $53 \%$ & $26 \%$ & $26 \%$ & $0 \%$ \\
\hline Transport service & 248 & $8 \%$ & $35 \%$ & $23 \%$ & $49 \%$ & $0 \%$ \\
\hline
\end{tabular}

Source: Adlung and Miroudot (2012).

\subsection{Service Rules in RTAs which Departure from GATS Multilateral Rules}

Trade agreements can help to promote international commerce by reducing barriers to foreign participation, making trade policies more transparent or enhancing the credibility of the trade regime. Besides commitments, the architectural choices and the liberalization mechanism design can be the key issues because different rules can entail different obligations for even the same commitments across different agreements. Regional service agreements have made innovation from various perspectives. Based on the existing research concerned including Latrille and Lee(2012), Roy et.al(2006)、Roy（2011）、 Adlung and Mamdouh(2013) etc, the representative rules in the regional level which departure from GATS can be summarized as follows and of course not just limited to these.

\subsubsection{Commitments Scheduled on Negative List}

The first key architectural choice concerns the approach towards scheduling trade commitments. Positive and negative listings are the two representative legal techniques. 
GATS have adopted the former, which means the market opening commitments can only apply to sectors and modes listed ${ }^{1}$. The commitments themselves are subject to limitations or conditions inscribed. Whether these limitations are for existing nonconforming measures or for future measures has not required to be indicated clearly (Roy et.al, 2006) . Moreover, since only "measures" are bound, no indication is given to the relevant laws/regulations, which will accentuates the lack of transparency (Roy et.al, 2006) .On the contrary, some RTAs followed the so called NAFTA-type which opted for a negative list, whereby market opening disciplines can apply to across-the-board except for scheduled reservations (including the existing non-conforming measures and the future measures). Under the negative list schedule, trade is unrestricted across all service activities unless a sector carve out or scheduled limitations applies ,which indicate the actual level of openness is spelled out by indication of the legal/regulatory framework in place(Roy et.al, 2006) .

In sum, though in principle the same level of openness can be realized by means of either a positive list or a negative one, the latter can provide greater transparency and lends greater credibility to service trade policies. In other words, knowing what is not allowed —rather than allowed — may help service providers better understand how they can do business in a foreign country. What's more, agreements using a negative list typically include a ratchet mechanism whereby any future liberalization of the reservations is automatically locked in which makes sure the actual policies will not become more restrictive.

\subsubsection{Comparative Liberal Rule of Origin}

In the case of services, rules of origin apply to "service providers" instead of the "service" itself. In general, three kinds of standard may be used to decide whether a certain service provider is eligible to benefit from preferential treatment or not. The first one( standard i ) is about “jurisdiction”(e.g. requiring a eligible juridical person should be constituted or organized under the laws of one of the parties, which means it should have a legal existence in the territory of a party. An eligible natural person should be a citizen or a permanent resident of a member). The second one (standard ii ) is about the "location"

\footnotetext{
${ }^{1}$ The sector commitment (market access and the national treatment)under the GATS is based on the positive list, while the most favored nation commitment is based on negative list ,so some experts think GATS followed the hybrid list approach(Latrille and Lee,2012).
} 
where the service provider carries out economic activities (e.g. requiring an eligible juridical person should have substantive business operations and a natural person should have the centre of economic interest in the territory of the party). The third one (standard iii) is according to the service provider's "ownership” or "control vested" (e.g. the benefit is limited to give the domestically owned or controlled service suppliers).

The majority of service RTAs adopt more liberal rules of origin than GATS. (1) GATS Article 28(m) set the rules of origin for juridical person on mode 1 and 2 based on the standard i and ii mentioned above, but when dealing with mode 3 the restrictive standard iii has been inscribed. On the contrary, most RTAs have not taken the standard iii into account when describing the eligible juridical person for mode 3 with a view to promoting third country FDI inflows into the integrating area and extending the benefits of integration to all investors that are established in one of the RTA Parties. (2) With regard to natural persons, GATS Article 28(k) sets the rules of origin based on both standard i and ii. But all RTAs just refer to standard $\mathrm{i}$, in which the definition of "nationals" and "permanent residents" is generally provided by the concerned party's national legislation (Miroudot et.al, 2010). Liberal rules of origin can help minimize the trade diversion effects, promote entry of the most efficient service providers but bear pay the cost of undermining the bargaining advantage of the members of RTAs in multilateral negotiations.

\subsubsection{Introduction of Non-party MFN.}

Most Favored Nation (MFN) treatment is a key obligation of GATS. Most service RTAs also include the similar provision which makes sure the parties to the agreement can receive treatment no less favorable than that granted to other parties. What's more, the MFN provision found in some RTAs also focuses on the treatment of parties versus non-parties, which requires the trade preferences accorded to non-parties should also extend to RTA parties. Though this non-party MFN clause can be subject to a negative list of reservations in general, the RTAs member has an incentive to ask for the non-party MFN treatment which ensures the domestic service providers will benefit from current and future trade preferences extended to non-parties (Fink and Molinuevo, 2007). From this perspective, the non-party MFN provision included in RTAs can help further 
promote the multilateralisation of regional commitments compared with the MFN commitment.

\subsubsection{Separate Rules on Service Investment.}

Under GATS, commercial presence has been defined as one of the supply modes (mode 3). Because there is no separate service investment chapter under GATS, which means the rules on service investment have been integrated into the rules on service trade. But many FTAs establish two different sets of disciplines on service investment. Service investment is not only regarded as a mode of supply in the services chapters but also be regulated by a separate investment chapter which can apply to goods and service investment horizontally. In general, the service investment has assumed different obligations under these two representative “integration” and "separation” frameworks. For example, besides foreign direct investment (FDI), the definition of investment under the horizontal investment disciplines is extended to include portfolio investment with many tangible and intangible properties. What's more, some regional trade agreements even subject investment in services (including mode 3) to extensive investment provisions including the liberalization clause (e.g. pre-establishment National Treatment clause), protection clause (expropriation, transfer of funds, umbrella clause, domestic regulation etc) and investor-state dispute settlements mechanism.

\section{3、Trade Effects of Service RTAs: Gravity Regression Analysis}

\subsection{Model Specification}

The gravity model is an important ex post method to estimate the determinants of trade flows. The model posits that bilateral trade flows are positively related to trading economies' size (GDP) but negatively related to the distance (Dist) between them. Recent years the gravity model has been applied to explore whether the formation of an RTA will change the bilateral trade flows. When doing so, the key and difficult challenge is how to correct for the biases emanating from the omission of the unobserved heterogeneity characterizing trading partner samples. Among all the omitted factors that can influence trade between pairs of countries, the most important one is the average trade cost of exporter and importer, the so-called "multilateral resistance term" (MRT) which was introduced by Anderson and van Wincoop (2003). However, given the 
difficulties of implementing the MRT, it has not been widely adopted in empirical research. Feenstra (2004) suggested taking it into account by including the countryspecific fixed effects in the gravity equation, which is a computationally easier route for the inclusion of multilateral price measures.

The MRT derived by Anderson and van Wincoop (2003) can only be applied in crosssection. Because cross-section analysis does not address the endogeneity bias of RTAs (the factors which affect trade flows can also affect the formation of a regional trade agreement, this means that the formation and deepening of an agreement and the trade flow might be correlated in case of self-selection) and no appropriate exogenous instrumental variables have been found to cope with this endogeneity bias. As a consequence, any gravity equation using cross-sectional data would tend to overstate or understate the true effect of the agreements. Under this condition, more and more recent research is resorting to panel data. Baldwin and Taglioni (2006) suggest generalizing the MRT in a panel setting by introducing the time-varying dummies to account for it. Considering the trade between any two countries depends on the multilateral resistance of both importers and exporters, following the idea of Baier and Bergstrand (2007) and Subramanian and Wei (2007) our paper uses time-varying fixed effects for both importers and exporters to account for factors specific to each country. The basic gravity equation of our paper is established as (1).

$$
\ln X_{i j t}=\beta_{1} \ln \left(G D P_{i t}\right)+\beta_{2} \ln \left(G D P_{j t}\right)+\beta_{3} \ln \left(D I S T_{i j}\right)+\beta_{4}\left(L A N G_{i j}\right)+\beta_{5}\left(R T A_{i j t}\right)+\eta_{i, t}+\eta_{j, t}+\varepsilon_{i j t}(1)
$$

Where $\mathrm{i}$ and $\mathrm{j}$ denote particular countries and t denotes time. $X_{i j t}$ denotes nominal bilateral exports in services from i to $\mathrm{j}$ at time t, $G D P_{i t}, G D P_{j t}$ are gross domestic product of country $\mathrm{i}$ and $\mathrm{j}, D_{S} T_{i j}$ is the distance between $\mathrm{i}$ and $\mathrm{j}, L A N G_{i j}$ is a common language dummy, $R T A_{i j t}$ is a binary variable that is unity if $\mathrm{i}$ and $\mathrm{j}$ belong to the same RTA. As mentioned above, $\eta_{i t}, \eta_{j t}$ in equation (1) are time-varying exporter and importer fixed effect which used to describe the multilateral trade resistance factor of Anderson and van Wincoop (2003) but which would vary over time. 
In the gravity equation (1), the main variable of interest is the time-varying dummy variable $R T A_{i j t}$ which takes a value of one if both countries are a member of the RTA and zero otherwise. In our paper only RTAs that were notified to WTO are included. If countries have only signed RTAs as a trading bloc, as in the case of the EU, each member economy is assumed to have formed a bilateral RTA. In order to distill the trade effects of $R T A_{i j t}$ on bilateral services trade into those emanating from “only goods" and “services” agreements, in gravity equation (2) we separate $R T A_{i j t}$ into $R T A^{\text {goods }}{ }_{i j t}$ and $R T A^{\text {serv }}{ }_{i j t}$. $R T A^{\text {goods }}{ }_{i j t}$ refers to RTAs which just cover the good trade liberalization, while the $R T A^{\text {serv }}{ }_{i j t}$ cover service trade liberalization and notify GATT/WTO under Article V of the GATS. Depending on the economic status of the two trading partners, this paper further divides $R T A^{s e r v}$ ijt into $R T A^{\text {serv }}{ }^{s s}$, $R T A^{\text {serv }}{ }_{i j t}^{N s}$ which indicates the service RTA signed between developing economies and between developed and developing economies separately.

$$
\begin{aligned}
& \ln X_{i j t}=\beta_{1} \ln \left(G D P_{i t}\right)+\beta_{2} \ln \left(G D P_{j t}\right)+\beta_{3} \ln \left(D I S T_{i j}\right)+\beta_{4}\left(L A N G_{i j}\right)+\beta_{5}\left(R T A_{i j t}^{g o o d s}\right)+\beta_{6}\left(R T A_{i j t}^{s e r v}\right)+\eta_{i, t}+\eta_{j, t}+\varepsilon_{i j t}(2) \\
& \ln X_{i j t}=\beta_{1} \ln \left(G D P_{i t}\right)+\beta_{2} \ln \left(G D P_{j t}\right)+\beta_{3} \ln \left(D I S T_{i j}\right)+\beta_{4}\left(L A N G_{i j}\right)+\beta_{5}\left(R T A_{i j t}^{g o o d s}\right)+\beta_{6}\left(R T A_{i j t}^{\text {serv }}\right)+\beta_{7}\left(R T A_{i j t}^{\text {serv }}\right)+ \\
& \eta_{i, t}+\eta_{j, t}+\varepsilon_{i j t}(3)
\end{aligned}
$$

The gravity models (4) and (5) are used to do empirical research on the trade effect from the perspective of the commitment of market access and national treatment separately. As mentioned previously, “GATS-Plus” and “GATS-Minus” have become the distinctive characteristics of RTAs and this paper aims to make a contribution at the empirical level by investigating and distinguishing the different effect of the "GATS-Plus" and “GATS-Minus” components of RTAs on the service trade .

$$
\begin{aligned}
& \ln X_{i j t}=\beta_{1} \ln \left(G D P_{i t}\right)+\beta_{2} \ln \left(G D P_{j t}\right)+\beta_{3} \ln \left(D I S T_{i j}\right)+\beta_{4}\left(L A N G_{i j}\right)+\beta_{5} \ln \left(M A^{G A T S}{ }_{i t, j}\right)+\beta_{6} \ln \left(M A^{G A T S}=_{i t, j}\right)+ \\
& \beta_{7} \ln \left(M A^{G A T S}{ }_{i t, j}\right)+\beta_{8} \ln \left(M A^{G A T S+}{ }_{j t, i}\right)+\beta_{9} \ln \left(M A^{G A T S}{ }_{j t, i}\right)+\beta_{10} \ln \left(M A^{G A T S}{ }_{j t, i}\right)+\eta_{i, t}+\eta_{j, t}+\varepsilon_{i j t}(4)
\end{aligned}
$$




$$
\begin{aligned}
& \ln X_{i j t}=\beta_{1} \ln \left(G D P_{i t}\right)+\beta_{2} \ln \left(G D P_{j t}\right)+\beta_{3} \ln \left(D_{S S T_{i j}}\right)+\beta_{4}\left(L_{A N G_{j}}\right)+\beta_{5} \ln \left(N T^{G A T S}{ }_{i t, j}\right)+\beta_{6} \ln \left(N T^{G A T S}{ }_{i t, j}\right) \\
& +\beta_{7} \ln \left(N T^{G A T S}{ }_{i t, j}\right)+\beta_{8} \ln \left(N T^{G A T S}{ }_{j t, i}\right)+\beta_{9} \ln \left(N T^{G A T S_{j}}{ }_{j, i}\right)+\beta_{10} \ln \left(N T^{G A T S}{ }_{j t, i}\right)+\eta_{i, t}+\eta_{j, t}+\varepsilon_{i j t}(5)
\end{aligned}
$$

$M A^{\mathrm{GATS}+}{ }_{i t, j}, M A^{\mathrm{GATS}=}{ }_{i t, j}, M A^{\mathrm{GATS}-}{ }_{i t, j}$ indicate the percentage of the subsectors of GNS/W/120 on which member i have made Market Access commitment to member $\mathrm{j}$ which has the characteristic of "GATS-plus"、 "GATS-neutral " and "GATS-minus" at

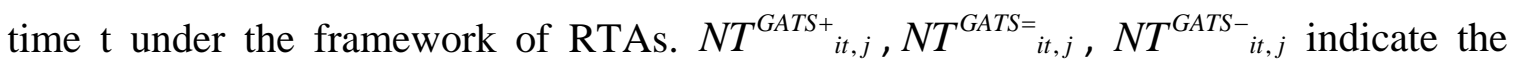
percentage of the subsectors of GNS/W/120 on which member i have made National Treatment commitment to member $\mathrm{j}$ which has the characteristic of "GATS-plus", "GATS-neutral " and "GATS-minus" at time t under the framework of RTAs. The variables $M A^{\text {GATS+ }}{ }_{j t, i}, M A^{G A T S=}{ }_{j t, i}, M A^{G A T S-}{ }_{j t, i}, N T^{G A T S+}{ }_{j t . i}, N T^{G A T S=}{ }_{j t, i}, N T^{G A T S-}{ }_{j t . i}$ have the similar economic definition but are used to describe the commitments which $\mathrm{j}$ have made to i.

\subsection{Sample and Data}

\subsubsection{Sample Economies}

This paper chooses 2000-2009 as the research period and selects 25 developed economies (Australia, Austria, Belgium, Canada, Czech Republic, Denmark, Finland, France, Germany, Greece, Hungary, Ireland, Italy, Japan, Luxembourg, Netherlands, New Zealand, Norway, Poland, Portugal, Spain, Sweden, Switzerland, United Kingdom, and United States) and 21 developing economies (Brazil, China, Chile, Egypt, Hongkong China, India, Indonesia, Israel, Korea, Macao China, Malaysia, Mexico , Russian, Singapore, South Africa, Taipei Chinese, Thailand, Turkey, Peru, Philippine and Viet Nam) as the sample economies. These 46 economies are all regarded as both home economies and trading partner. Each home economy in our sample is paired with a trading partner. So the unit of analysis is a trading pair.

When deciding which economy should be selected for the sample, the following two important factors are considered: (1) in recent years the leading service exporters and importers of the world ( United States, Germany, United Kingdom, China, France, 
Japan, Spain, Singapore, Netherlands, India, Hongkong China, Italy, Ireland, Korea, Belgium, Switzerland, Luxembourg, Canada, Sweden, Denmark, Austria, Australia, Russian, Taipei Chinese, Norway, Greece, Thailand, Turkey, Malaysia, Poland, Brazil ,Macao China, Finland, Egypt, Portugal) and the most important bilateral service trade partners in the world(United States- United Kingdom, United States- Japan, United Kingdom -United States, United States- Canada, Canada -United States, Japan- United States, Germany- United States, United States -Germany, France -

United States, United States- Mexico, Australia-Germany, France - United Kingdom, Italy- Germany, United States- France, Hongkong China- China, Germany- United Kingdom, United Kingdom- Germany) should be covered.(2) Because the key variable in our research is $R T A_{i j t}$ especially $R T A_{i j t}^{\text {serv }}$, the active members which participate in the process of regional service liberalization should also be covered. According to the WTO database, 133 RTAs covering services have been notified under GATS Article V at the end of January 2014, of which 118 RTAs were in force. The sample economies had taken part in 109 of them (occupied more than 90\%).

\subsubsection{Data}

The dependant variable of the gravity equation represents either exports or imports between countries, but exports are generally better recorded and more widely adopted by researchers. So this paper chooses bilateral exports in services as the dependant variable which is drawn from the OECD statistics database on international trade in services (http://stats.oecd.org/wbos/Index.aspx?DatasetCode=TISP). The exports of Australia, Belgium, Canada, Czech Republic, Denmark, Finland, France, Germany, Greece, Hongkong China, Hungry , Ireland, Italy, Japan, Korea, Russia, Poland, Portugal, Spain, Sweden, Luxembourg, Netherland, New Zealand, Norway, United Kingdom, United States are all downloaded from the OECD database directly while the export of other economies are deducted from the import of its trading partner. Services exports are expressed in millions of US \$. 
GDP data measured at current prices and also expressed in million US \$. GDP data comes from IMF World Economic Outlook Database ${ }^{2}$. GDP of Macao China comes from Statistics and Census Service of Macao Special Administrative Region ${ }^{3}$. Followed Baldwin and Taglioni (2006) which highlight the importance of using nominal trade and nominal GDPs instead of the real one in order to avoid the bias due to conversion factors between US dollars in different years, our paper also choose nominal trade flows and nominal GDPs. Geographical distance between two economies is calculated by measuring the distance between the capitals of two economies which take from Indocom (http://www.indocom.com/distance). $L A N G_{i j}$ is a dummy variable that takes the value 1 if two countries have the same language .Sample economies' official language is taken from the CIA's Fact book. The value of a series of dummy variables including $R T A_{i j t}$, $R T A^{\text {goods }}{ }_{i j t}, R T A^{\text {serv }}{ }_{i j t}, R T A^{s e r v^{s s}}{ }_{i j t}, R T A^{s e r v^{N S}}$ ijt are all depending on the RTA database of WTO.

\subsubsection{More on Variables concerning “GATS-Plus" “GATS-neutral” and "GATS- Minus"}

When it comes to $N T^{\text {GATS+ }}{ }_{i t, j}, N T^{\text {GATS }=}{ }_{i t, j}, N T^{\text {GATS- }}{ }_{i t, j}, M A^{\text {GATS+ }}{ }_{i t, j}, M A^{\text {GATS }=}{ }_{i t, j}$, $M A^{\text {GATS- }}{ }_{i t, j}, N T^{\text {GATS+ }}{ }_{j t . i}, N T^{\text {GATS= }}{ }_{j t, i}, N T^{\text {GATS- }}{ }_{j t . i}, M A^{\text {GATS+ }}{ }_{j t, i}, M A^{\text {GATS= }}{ }_{j t, i}, M A^{\text {GATS- }}{ }_{j t, i}$, these twelve variables are not dummy variables but continuous ones.Their values are calculated by authors based on Table 6 in annex 3 of Miroudot et.al (2010). Here we just take $N T^{\text {GATS+ }}{ }_{i t, j}, N T^{\text {GATS }=}{ }_{i t, j}, N T^{\text {GATS- }}{ }_{i t, j}, M A^{\text {GATS+ }}{ }_{i t, j}, M A^{\text {GATS= }}{ }_{i t, j}, M A^{\text {GATS- }}{ }_{i t, j}$ for examples to explain the rules how to value these variables in several different cases ${ }^{4}$.

Case1: if trading pair $\mathrm{i}$ and $\mathrm{j}$ had never signed any $R T A^{\text {serv }}{ }_{i j t}$ with each other during the research period (2000-2009), the value of $N T_{i t, j}^{G A T S+} N T_{i t, j}^{G A T S-}, A^{G A T S+}{ }_{i t, j}$, $M A^{\text {GATS- }}{ }_{i t, j}$ equal to 0 but $N T^{\text {GATS }}{ }_{i t, j}$ and $M A^{\text {GATS }}{ }_{i t, j}$ equal to $100 \%$. It means under the

\footnotetext{
${ }^{2}$ http://www.imf.org/external/pubs/ft/weo/2011/02/weodata/weoselgr.aspx

${ }^{3}$ http://www.dsec.gov.mo/PredefinedReport.aspx?lang=en-US\&ReportID=32.

${ }^{4}$ The rules to value the $N T^{\text {GATS+ }}{ }_{j t . i}, N T^{\text {GATS }=}{ }_{j t, i}, N T^{\text {GATS- }}{ }_{j t . i}, M A^{\text {GATS }+}{ }_{j t, i}, M A^{\text {GATS }=}{ }_{j t, i}$, $M A^{\text {GATS- }}{ }_{j t, i}$ is the same.
} 
framework of RTAs, economy i had never made any commitment of "GATS-plus" or "GATS-minus" nature to economy $\mathrm{j}$, all the treatment i promised to give $\mathrm{j}$ is just "GATSneutral".

Case 2: if trading pair $\mathrm{i}$ and $\mathrm{j}$ had just signed one $R T A^{\text {serv }}{ }_{i j t}$ with each other at year $\mathrm{T}_{1}$ during the research period (2000-2009), then from year $\mathrm{T}_{1}$ and later, $N T^{\mathrm{GATS}}{ }_{i t, j}$, $N T^{\text {GATS- }}{ }_{i t, j}$ and $M A^{\text {GATS+ }}{ }_{i t, j}, M A^{\text {GATS- }}{ }_{i t, j}$ should be the corresponding percentage of "GATS-plus" and "GATS-minus" commitment on National Treatment and Market Access that $\mathrm{i}$ had made to $\mathrm{j}$ in this RTA that list in table 6 of Miroudot et.al (2010). For example, if these figures for $N T^{G A T S+}{ }_{i t, j}, N T^{G A T S-}{ }_{i t, j}, M A^{G A T S+}{ }_{i t, j}, M A^{G A T S-}{ }_{i t, j}$ are $\mathrm{n}_{1} \%, \mathrm{n}_{2} \%, \mathrm{~m}_{1} \%, \mathrm{~m}_{2} \%$, then the corresponding $N T^{G A T S=}{ }_{i t, j}, M A^{G A T S=}{ }_{i t, j}$ equal to $\left(1-\mathrm{n}_{1} \%-\mathrm{n}_{2} \%\right)$

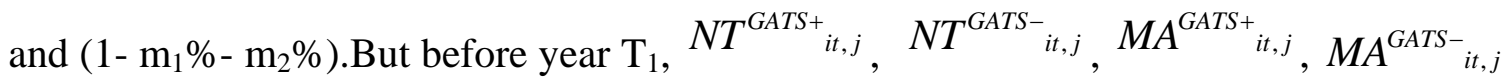
are all equal to 0 and $N T^{G A T S=}{ }_{i t, j}, M A^{G A T S=}{ }_{i t, j}$ equal to1.

Case3: if trading pair $\mathrm{i}$ and $\mathrm{j}$ had signed more than one $R T A^{\text {serv }}{ }_{i j t}$ with each other during the research period (2000-2009). For example, if at year $T_{1}$ and $T_{2}$, economy $i$ and j signed service RTA $A_{1}$ and RTA $A_{2}$ separately. Under the framework of $\mathrm{RTA}_{1}\left(\mathrm{RTA}_{2}\right)$, the percentage of "GATS+" 、 "GATS-" commitment on Nation Treatment and on Market Access which drawn from table 6 of Miroudot et.al (2010) is $\mathrm{n}_{1, \mathrm{~T} 1} \%, \mathrm{n}_{2, \mathrm{~T} 1} \%$, $\mathrm{m}_{1, \mathrm{~T} 1} \%, \mathrm{~m}_{2, \mathrm{~T} 1} \%\left(\mathrm{n}_{1, \mathrm{~T} 2} \%, \mathrm{n}_{2, \mathrm{~T} 2} \%, \mathrm{~m}_{1, \mathrm{~T} 2} \%, \mathrm{~m}_{2, \mathrm{~T} 2} \%\right)$.

Then from year 2000 to year $\mathrm{T}_{1}-1$, the value of $N T^{\text {GATS }}{ }_{i t, j}, \quad N T^{\text {GATS- }}{ }_{i t, j}, M A^{\text {GATS+ }}{ }_{i t, j}$, $M A^{\text {GATS- }}{ }_{i t, j}$ equal to 0 , while $N T^{G A T S=}{ }_{i t, j}, M A^{G A T S=}{ }_{i t, j}$ equal to $100 \%$.

From year $\mathrm{T}_{1}$ to year $\mathrm{T}_{2}-1$, the value of $N T^{\text {GATS }}{ }_{i t, j}, \quad N T^{\text {GATS- }}{ }_{i t, j}, M A^{\text {GATS+ }}{ }_{i t, j}$, $M A^{\text {GATS- }}{ }_{i t, j}$ equal to $\mathrm{n}_{1, \mathrm{~T} 1} \%, \mathrm{n}_{2, \mathrm{~T} 1} \%, \mathrm{~m}_{1, \mathrm{~T} 1} \%, \mathrm{~m}_{2, \mathrm{~T} 1} \%$, while $N T^{\text {GATS= }}{ }_{i t, j}, M A^{\text {GATS }}{ }_{i t, j}$ equal to (1- $\left.\mathrm{n}_{1, \mathrm{~T} 1} \%-\mathrm{n}_{2, \mathrm{~T} 1} \%\right),\left(1-\mathrm{m}_{1, \mathrm{~T} 1} \%-\mathrm{m}_{2, \mathrm{~T} 1} \%\right)$.

From year $\mathrm{T}_{2}$ to year 2009, the value of $N T^{\text {GATS+ }}{ }_{i t, j}, \quad N T^{\text {GATS- }}{ }_{i t, j}, M A^{\text {GATS+ }}{ }_{i t, j}$, $M A^{\text {GATS- }}{ }_{i t, j}$ equal to $\max \left(\mathrm{n}_{1, \mathrm{~T} 1} \%, \mathrm{n}_{1, \mathrm{~T} 2} \%\right), \min \left(\mathrm{n}_{2, \mathrm{~T} 1} \%, \mathrm{n}_{2, \mathrm{~T} 2} \%\right), \max \left(\mathrm{m}_{1, \mathrm{~T} 1} \%, \mathrm{~m}_{1, \mathrm{~T} 2} \%\right)$, $\min \left(\mathrm{m}_{2, \mathrm{~T} 1} \%, \mathrm{~m}_{2, \mathrm{~T} 2} \%\right)$, while $N T^{\mathrm{GATS}}{ }_{i t, j}, M A^{\mathrm{GATS}}{ }_{i t, j}$ equal to $1-\max \left(\mathrm{n}_{1, \mathrm{~T} 1} \%, \mathrm{n}_{1, \mathrm{~T} 2} \%\right)-$ $\min \left(\mathrm{n}_{2, \mathrm{~T} 1} \%, \mathrm{n}_{2, \mathrm{~T} 2} \%\right)$ and $1-\max \left(\mathrm{m}_{1, \mathrm{~T} 1} \%, \mathrm{~m}_{1, \mathrm{~T} 2} \%\right)-\min \left(\mathrm{m}_{2, \mathrm{~T} 1} \%, \mathrm{~m}_{2, \mathrm{~T} 2} \%\right)$. 


\subsubsection{Descriptive Statistics}

\section{TABLE 4}

Summary Statistics for the Data used in the Estimation

\begin{tabular}{|c|c|c|c|c|c|c|c|c|c|c|c|}
\hline Variable & Observation & Mean & Std. Dev. & Min & Max & Variable & Observation & Mean & Std. Dev. & Min & Max \\
\hline $\ln X_{i j t}$ & 13161 & 5.2631 & 2.3176 & -6.6918 & 11.0610 & $\ln M A^{G A T S=}{ }_{i t, j}$ & 13161 & -0.0537 & 0.2373 & -1.6874 & 0 \\
\hline $\ln \left(G D P_{i t}\right)$ & 13161 & 6.0427 & 1.3058 & 1.8566 & 9.5674 & $\ln M A^{\text {GATS- }}{ }_{i t, j}$ & 13161 & -13.5531 & 1.5267 & -13.8155 & -1.2208 \\
\hline $\ln \left(G D P_{j t}\right)$ & 13161 & 6.0141 & 1.3015 & 1.8566 & 9.5674 & $\ln M A^{G A T S+}{ }_{j t, i}$ & 13161 & -12.9694 & 3.1772 & -13.8155 & -0.2169 \\
\hline $\ln \left(D I S T_{i j}\right)$ & 13161 & 8.4164 & 1.0409 & 5.1417 & 9.8824 & $\ln M A^{G A T S=}{ }_{j t, i}$ & 13161 & -0.0543 & 0.2383 & -1.6874 & 0 \\
\hline$L A N G_{i j}$ & 13161 & 0.1493 & 0.3564 & 0 & 1 & $\ln M A^{G A T S-}{ }_{j t, i}$ & 13161 & -13.5514 & 1.5328 & -13.8155 & -1.2208 \\
\hline$R T A_{i j t}$ & 13161 & 0.3764 & 0.4845 & 0 & 1 & $\ln N T_{i t, j}^{G A T S+}$ & 13161 & -13.0032 & 3.0826 & -13.8155 & -0.2157 \\
\hline$R T A_{i j t}^{\text {goods }}$ & 13161 & 0.3714 & 0.4832 & 0 & 1 & $\ln N T^{G A T S=}{ }_{i t, j}$ & 13161 & -0.0500 & 0.2297 & -2.0326 & 0 \\
\hline$R T A^{\text {serv }}{ }_{i j t}$ & 13161 & 0.2627 & 0.4401 & 0 & 1 & $\ln N T^{\text {GATS- }}{ }_{i t, j}$ & 13161 & -13.5471 & 1.5752 & -13.8155 & -1.1457 \\
\hline$R T A^{\operatorname{serv} N S} i j t$ & 13161 & 0.0479 & 0.2135 & 0 & 1 & $\ln N T^{G A T S=}{ }_{j t, i}$ & 13161 & -0.0508 & 0.2313 & -2.0326 & 0 \\
\hline $\ln M A^{G A T S+}{ }_{i t, j}$ & 13161 & -12.9742 & 3.1719 & -13.8155 & -0.2169 & $\ln N T^{\text {GATS- }}{ }_{j t, i}$ & 13161 & -13.5506 & 1.5656 & -13.8155 & -1.1457 \\
\hline
\end{tabular}

The gravity regression analysis in our study uses annual data consisting of 20700(46*45*10) trading-pairs in total. The dataset features a panel structure by covering 46 economies for ten years from 2000 to 2009. The number of observations varies per year. Preliminary evaluation of the data revealed that 30 trading partners report negative services exports. These observations were excluded from the sample. In addition, data on services exports was found missing for 7305 observations over 2000-2009, which effectively reduces the sample size by that number. After dropping the observations with missing data, 13161 observations with complete data left. Table 4 shows the mean value for our sample variables, along with the minimum, maximum and the standard deviation.

Through investigation of the data, the following findings can be noted:

(1)Of all the 13161 observations, 4954 trading-pairs (37.64percent) belong to RTAs, 4888 trading-pairs (37.14percent) belong to goods RTAs and 3458 trading-pairs (26.28 percent) belong to service RTAs. Among all the service RTAs, 18.21 percent (630 trading-pairs) of which were signed between developed economies and developing economies, while 1.7351percent (60 country-pairs) were signed between developing economies. 


\section{TABLE 5}

Summary Statistics for Service Export Data in Subsample

\begin{tabular}{ccccc}
\multicolumn{5}{c}{ (Based on the variable concerned "RTA", "RTA goods”, and "RTA ${ }^{\text {service,") }}$} \\
\hline $\ln X_{i j t}$ & ALL members & $\begin{array}{l}\text { Members belong } \\
\text { to } R T A_{i j t}\end{array}$ & $\begin{array}{l}\text { Members belong } \\
\text { to } R T A^{\text {goods }}\end{array}$ & $\begin{array}{c}\text { Members belong } \\
\text { to } R T A^{\text {serv }}{ }_{i j t}\end{array}$ \\
\hline Observation & 13161 & 4954 & 4888 & 3458 \\
Mean & $\mathbf{5 . 2 6 3 1}$ & $\mathbf{6 . 0 3 7 7}$ & $\mathbf{6 . 0 6 8 3}$ & $\mathbf{6 . 3 2 8 0}$ \\
Max & 11.0610 & 10.7204 & 10.7204 & 10.7204 \\
Min & -6.6918 & --6.69184 & -1.09287 & -6.69184 \\
Std. Dev. & 2.3176 & 1.97689 & 1.93109 & 1.918166 \\
\hline
\end{tabular}

(2)Table 5 indicates the trade-creating effect of RTAs is much significant. The average level of bilateral aggregate service trade between RTA members is 2.1695( $\left.\exp ^{6.0377} / \exp ^{5.2631}\right)$ times as high as the average bilateral service trade in the whole sample. The figure corresponding to goods RTAs and service RTAs are 2.2371 $\left(\exp ^{6.0683} / \exp ^{5.2631}\right)$ times and $2.9005\left(\exp ^{6.3280} / \exp ^{5.2631}\right)$ times respectively. It implies signing RTAs may help to promote the service trade between members.

(3) Table 6 shows of all the 3458 observations covered by service RTAs, almost 30\% of the trading-pairs have make the "GATS+" commitment to each other and about $10 \%$ of the trading-pairs have make the "GATS-" commitment to each other (the first row of table 6 indicate the number of the observations whose $M A^{G A T S+}{ }_{i t, j}, N T^{\mathrm{GATS}+}{ }_{i t, j}, M A^{\mathrm{GATS}}{ }_{j t, i}$, $N T^{\text {GATS }}{ }_{j t, i}, M A^{\text {GATS- }}{ }_{i t, j}, N T^{\text {GATS- }}{ }_{i t, j}, M A^{\text {GATS }-~}{ }_{j t, i}, N T^{\text {GATS }}{ }_{j t, i}$ are positive are 873,873,880,880, $389,384,391,391)$.

Table 6 also shows the mean of $\ln X_{i j t}$ in subsample named $M A^{\mathrm{GATS}+}{ }_{i t, j}>0$ and ${ }_{M A^{\mathrm{GATS}+}}{ }_{j, i}>0$ $\left(N T^{\text {GATS }}{ }_{i t, j}>0\right.$ and $N T^{\text {GATS }}{ }_{j t, i}>0$ ) are larger than corresponding figures in subsample named “ $M A^{\mathrm{GATS}}{ }_{i t, j}=0$ ” and $M A^{\mathrm{GATS}+}{ }_{j t, i}=0 \quad\left(N T^{\mathrm{GATS}+}{ }_{i t, j}=0\right.$ and $\left.N T^{\mathrm{GATS}+}{ }_{j t, i}=0\right)$, which may means the "GATS+" component( either in market access commitment or in national treatment ) in the framework of RTA can help to increase the service trade between members.

It is surprising that the mean of $\ln X_{i j t}$ in subsample named $M A^{\mathrm{GATS}-}{ }_{i t, j}>0$ and $M^{\mathrm{GATS}-}{ }_{j t, i}>0$ $\left(N T^{\text {GATS }}{ }_{i t, j}>0\right.$ and $N T^{\text {GATS }_{j t, i}}>0$ ) are not less than corresponding figures in subsample named “ $M A^{\mathrm{GATS}-}{ }_{i t, j}=0$ ” and $M A^{\mathrm{GATS}-}{ }_{j t, i}=0\left(N T^{\mathrm{GATS}}{ }_{i t, j}=0\right.$ and $\left.{ }_{N T}^{\mathrm{GATS}-}{ }_{j t, i}=0\right)$, which may means 
the "GATS-" component( either in market access commitment or in nation treatment ) in the framework of RTAs may not reduce the bilateral service export which is out of our expectation.

The above observations seemed reasonable but they are subject to some limitations. When the trade effect of the RTAs and specific commitments are interpreted, other variables are not appropriately controlled so the result may be biased as a consequence and should be tested further.

\section{TABLE 6}

Summary Statistics for Service Export Data in Subsamples

(Based on the variable concerned "GATS+" and "GATS-")

\begin{tabular}{|c|c|c|c|c|c|c|c|c|}
\hline $\ln X_{i j t}$ & $M A^{\text {GATS }+}{ }_{i t, j}=0$ & $M A^{\text {GATS + }}{ }_{i t, j}>0$ & $M A^{\text {GATS }-}{ }_{i t, j}=0$ & $M A^{\text {GATS- }}{ }_{i t, j}>0$ & $N T^{\text {GATS + }}{ }_{i t, j}=0$ & $N T^{\text {GATS }+}{ }_{i t, j}>0$ & $N T^{\text {GATS- }}{ }_{i t, j}=0$ & $N T^{\text {GATS }-}{ }_{i t, j}>0$ \\
\hline Observation & 12288 & 873 & 12772 & 389 & 12288 & 873 & 12777 & 384 \\
\hline Mean & 5.2476 & 5.4811 & 5.2598 & 5.3699 & 5.2476 & 5.4811 & 5.2594 & 5.3680 \\
\hline Max & 11.0610 & 10.7204 & 11.0610 & 10.7204 & 11.0610 & 10.7204 & 11.0610 & 10.7204 \\
\hline Min & -6.6918 & -6.6918 & -6.6918 & -6.6918 & -6.6918 & -6.6918 & -6.6918 & -6.6918 \\
\hline Std. Dev. & 2.3115 & 2.3925 & 2.2986 & 2.8726 & 2.3114 & 2.3926 & 2.2981 & 2.8942 \\
\hline
\end{tabular}

\begin{tabular}{|c|c|c|c|c|c|c|c|c|}
\hline $\ln X_{i j t}$ & $M A^{\text {GATS }+}{ }_{j t, i}=0$ & $M A^{\text {GATS + }}{ }_{j t, i}>0$ & $M A^{\text {GATS - }}{ }_{j t, i}=0$ & $M A^{\text {GATS - }}{ }_{j t, i}>0$ & $N T^{\text {GATS + }}{ }_{j t, i}=0$ & $N T^{\text {GATS + }}{ }_{j t, i}>0$ & $N T^{\text {GATS- }}{ }_{j t, i}=0$ & $N T^{\text {GATS - }}{ }_{j t, i}>0$ \\
\hline Observation & 12281 & 880 & 12770 & 391 & 12281 & 880 & 12782 & 391 \\
\hline Mean & 5.2422 & 5.5546 & 5.2595 & 5.3820 & 5.2422 & 5.5546 & 5.2602 & 5.3820 \\
\hline Max & 11.0610 & 10.7204 & 11.0610 & 10.7204 & 11.0610 & 10.7204 & 11.0610 & 10.7204 \\
\hline Min & -6.6918 & -6.6918 & -6.6918 & -6.6918 & -6.6918 & -6.6918 & -6.6918 & -6.6918 \\
\hline Std. Dev. & 2.3125 & 2.3695 & 2.2987 & 2.8674 & 2.3124 & 2.3695 & 2.2977 & 2.8674 \\
\hline
\end{tabular}

\section{Results}

In order to investigate the determinants of bilateral service trade, we use the gravity equation with time-varying exporter and importer fixed effect $\left(\eta_{i, t}\right.$ and $\left.\eta_{j, t}\right)$ as the main regression model and apply the gravity equation with specific exporter and importer fixed effect $\left(\eta_{i}, \eta_{j}\right)$ and year fixed effect ( $\left.\eta_{t}\right)$ to do the robustness test( see table 7 and 8 ). The regression results of these two methods indicate GDPs of both home and partner economy and a shared language between trading partners can all hold a significantly positive relationship with exports in services, while the distance between trading partners hold statistically negative relationship (row 1-4 of table 7 and 8). These findings conform to the basic gravity theory and previous work in the literature. 


\subsection{Agreements and Trade in Services}

When it comes to how the membership of regional trade agreement can impact trade in services, according to the columns (1-2) of Table 7, the coefficient of RTA in model 1 is positive (0.2099441 and 0.300722) and statistically significant, which means belong to a RTA can increase the bilateral service export from economy i to j by 23-35\%. This result supports the findings of most previous literatures e.g. Grünfeld and Moxnes (2003), Kimura and Lee (2006), Baier and Bergstrand (2007) and Guillin (2013).

TABLE 7

Effect of RTAs on Trade in Services by Type

\begin{tabular}{|c|c|c|c|c|c|c|}
\hline & Model1 & Model1 & Model2 & Model2 & Model3 & Model3 \\
\hline $\ln \left(G D P_{i t}\right)$ & $\begin{array}{c}0.8688025^{* * *} \\
(0.2286815)\end{array}$ & $\begin{array}{c}0.5876715^{* * *} \\
(0.0691117)\end{array}$ & $\begin{array}{c}0.8452989 * * * \\
(0.2284443)\end{array}$ & $\begin{array}{c}0.579535 * * * \\
(0.0690489)\end{array}$ & $\begin{array}{c}0.8863912^{* * *} \\
(0.2274732)\end{array}$ & $\begin{array}{c}0.5961367 * * * \\
(0.0689041)\end{array}$ \\
\hline $\ln \left(G D P_{j t}\right)$ & $\begin{array}{l}1.265708 * * * \\
(0.2289838)\end{array}$ & $\begin{array}{c}0.8545463 * * * \\
(0.0667316)\end{array}$ & $\begin{array}{c}1.242834 * * * \\
(0.228743)\end{array}$ & $\begin{array}{c}0.8395157 * * * \\
(0.0667404)\end{array}$ & $\begin{array}{c}1.28435 * * * \\
(0.227775)\end{array}$ & $\begin{array}{c}0.8599056 * * * \\
(0.0665158)\end{array}$ \\
\hline $\ln \left(D I S T_{i j}\right)$ & $\begin{array}{c}-1.010839 * * * \\
(0.015041)\end{array}$ & $\begin{array}{c}-0.9961365^{* * *} \\
(0.01465)\end{array}$ & $\begin{array}{c}-0.9869529 * * * \\
(0.0154672)\end{array}$ & $\begin{array}{c}-0.9745432^{* * *} \\
(0.0150048)\end{array}$ & $\begin{array}{c}-1.031521 * * * \\
(0.0153022)\end{array}$ & $\begin{array}{c}-1.007929 * * * \\
(0.0148455)\end{array}$ \\
\hline$L A N G_{i j}$ & $\begin{array}{c}0.4024248 * * * \\
(0.0268439)\end{array}$ & $\begin{array}{c}0.4061612^{* * * *} \\
(0.027276)\end{array}$ & $\begin{array}{c}0.4040852 * * * \\
(0.0268236)\end{array}$ & $\begin{array}{c}0.4082011^{* * *} \\
(0.0272478)\end{array}$ & $\begin{array}{c}0.3922573^{* * *} * \\
(0.0267419)\end{array}$ & $\begin{array}{c}0.4007534 * * * \\
(0.0272131)\end{array}$ \\
\hline$R T A_{i j t}$ & $\begin{array}{c}0.2099441 * * * \\
(0.034455)\end{array}$ & $\begin{array}{c}0.300722 * * * \\
(0.031167)\end{array}$ & & & & \\
\hline$R T A^{g o o d s} s_{i j t}$ & & & $\begin{array}{c}0.1536971 * * * \\
(0.0439541)\end{array}$ & $\begin{array}{c}0.2447556^{* * *} \\
(0.0408463)\end{array}$ & $\begin{array}{c}0.0974449 * * * \\
(0.0370078)\end{array}$ & $\begin{array}{c}0.2304169 * * * \\
(0.033619)\end{array}$ \\
\hline$R T A^{\text {serv }}{ }_{i j t}$ & & & $\begin{array}{c}0.1679706^{* * * *} \\
(0.0467809)\end{array}$ & $\begin{array}{c}0.1575548 * * * \\
(0.0446082)\end{array}$ & & \\
\hline$R T A_{i j t}^{s e r v^{S S}}$ & & & & & $\begin{array}{c}0.7092921 * * * \\
(0.1360395)\end{array}$ & $\begin{array}{c}0.5306466 * * * \\
(0.1325242)\end{array}$ \\
\hline$R T A^{\text {serv }}{ }_{i j t}^{N S}$ & & & & & $\begin{array}{c}0.7413404^{* * *} \\
(0.0695882)\end{array}$ & $\begin{array}{c}0.524256 * * * \\
(0.0641395)\end{array}$ \\
\hline Observations & 13160 & 13160 & 13160 & 13160 & 13160 & 13160 \\
\hline $\mathrm{F}$ & $\begin{array}{c}\mathrm{F}(902,12257)=79.6 \\
9\end{array}$ & $F(104,13005)=652.09$ & $F(903,12256)=79.83$ & $F(105,13054)=648.04$ & $F(904,12255)=80.52$ & $F(106,13053)=645.23$ \\
\hline Prob $>F$ & 0.0000 & 0.0000 & 0.0000 & 0.0000 & 0.0000 & 0.0000 \\
\hline R-squared & 0.8543 & 0.8386 & 0.8547 & 0.8390 & 0.8559 & 0.8397 \\
\hline $\begin{array}{l}\text { Adj R-squared } \\
\text { Fixed effect }\end{array}$ & 0.8436 & 0.93483 & 0.8440 & 0.8377 & 0.8453 & 0.8384 \\
\hline exporter-year $\left(\eta_{i, t}\right)$ & $\sqrt{ }$ & & $\sqrt{ }$ & & $\sqrt{ }$ & \\
\hline importer-year $\left(\eta_{j, t}\right)$ & $\sqrt{ }$ & & $\sqrt{ }$ & & $\sqrt{ }$ & \\
\hline $\operatorname{exporter}\left(\eta_{i}\right)$ & & $\sqrt{ }$ & & $\sqrt{ }$ & & $\sqrt{ }$ \\
\hline $\operatorname{importer}\left(\eta_{j}\right)$ & & $\sqrt{ }$ & & $\sqrt{ }$ & & $\sqrt{ }$ \\
\hline year $\left(\eta_{t}\right)$ & & $\sqrt{ }$ & & $\sqrt{ }$ & & $\sqrt{ }$ \\
\hline
\end{tabular}

NOTE: (1) Standard errors are in parentheses. Intercept is included but not reported. (2)*, **, *** indicate that the estimated coefficients are statistically significant at $10 \%, 5 \%$ and $1 \%$ respectively.

When distinguishing $R T A_{i j t}$ as “only goods” agreements and "services” agreements, columns (3) of table 7 suggest that $R T A_{i j t}^{\text {goods }}$ and $R T A^{\text {serv }}{ }_{i j t}$ can make service exports from $\mathrm{i}$ to $\mathrm{j}$ significantly increased by $16.61 \%$ and $18.29 \%$ respectively .The corresponding figures based on the result of gravity model with specific exporter and 
importer fixed effect $\left(\eta_{i}, \eta_{j}\right)$ and year fixed effect $\left(\eta_{t}\right)$ (column 4 of table 7)are $27.73 \%$ and $17.06 \%$. Though these results do not allow us to conclude precisely whether $R T A^{\text {goods }}{ }_{i j t}$ or $R T A^{\text {serv }}{ }_{i j t}$ can have larger effect on bilateral service export. The most important thing to note is the positive and significant coefficients of both variables. The effect of $R T A^{\text {goods }}{ }_{i j t}$ appears to reflect the impact of bilateral trade in goods on services trade, which means service export can be promoted by the "only goods" RTAs through raising member's bilateral goods trade.

When taking the economic development level of the members into account, $R T A^{\text {serv }}{ }_{i j t}$

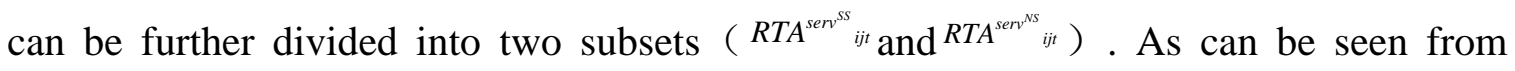
Table 7, the trade-enhancing effects of both categories are significantly high and almost the same. In detail, column 5 of Table 7 shows $R T A^{\text {servs }}{ }_{i j t}^{\text {con }}$ can increase bilateral service export by $109.87 \%$ and $R T A^{\operatorname{sen}^{\text {es }}}$ it can increase this by $103.26 \%$. The corresponding figures which come from the second gravity model are lower, Column 6 of Table 7 indicates $R T A^{s e r s}{ }_{i j t}, R T A^{s e r n s}{ }_{i j t}$ can help to promote the service export from i to j increasing by $70.00 \%$ and $68.92 \%$.

\section{2 "GATS+"“GATS="and "GATS-" Commitments in RTAs and Trade in Services}

In order to decide on trade policies, it is useful to better understand the real impact of "GATS-Plus”, “GATS-neutral” and "GATS-Minus” components of RTAs on trade in services. According to Table 8, the following conclusions can be drawn from the regression results.

(1) Almost all the "GATS-plus" and "GATS-neutral" commitments either on market access or on national treatment made by trading-pairs with each other can have a significantly positive effect on bilateral service export, which complied with our expectation. It should be noted that Table 8 also shows the trade creating effect of "GATS-neutral" commitments are comparatively larger than that of "GATS-plus" commitments. Two factors may lead to this result. First, though the "GATS-plus" commitment cannot be ignored, the most protected services activities in large countries especially the developed ones remain largely unaffected by RTAs despite some improvements on the fringes (Roy et.al, 2006). As a result, the commitments of "GATS- 
neutral” nature remains the main rules which regulate the global services trade. "GATSplus” commitments are the minority part of the service trading system and of course can have comparative limited effects. Second, though some economies have made the commitments which surpass the GATS by either making an improvement in existing commitments or new sectors scheduled. The "GATS-plus" commitments just indicate the bound level of discrimination permitted within the RTA and do not describe the actual trade regime. Because actual trade barriers in services are often known to be different from the bound level of non-discrimination. In brief, a "GATS-plus” commitment does not always lead to the preferential treatment in practice, which would nullify the trade creating effect.

(2)The commitments of “GATS-minus” characteristics on market access and national treatment under RTAs do not have a significant effect on bilateral service exports. Why do the negative commitments not reduce the trade flow as we have expected? In sum, "GATS-minus" commitments can be neutralized to some extent by two main mechanisms under the RTAs: "liberal rule of origin" and "the non-party MFN provisions". The rules of origin for services providers under the RTAs are generally portrayed as liberal, which potentially enables non-parties to indirectly benefit from the more favorable treatment granted in RTAs to services providers of the parties (Baldwin and Harrigan, 2008; Fink and Molinuevo, 2007). Indeed, adopting liberal rules of origin can to some extent be a way of reintroducing the MFN principle back into the RTAs. What's more, as pointed out in section 2, more and more RTAs include the MFN provisions with respect to non-parties which can provide a mechanism to extend the preferential treatment of the most ambitious agreements to more parties , of which of course includes the members which have been given the "GATS-minus” treatments.

Now the problem comes to why the RTAs are willing to include these two preference erosion mechanism, the following several factors may help to explain. First, the rationale for doing so is to overcome the economic distortions and productivity loss which caused by letting the less competitive service provider first enters the market on a preference basis. Because of sunk costs and the first mover advantage, the entry of the more competitive firms at a later stage can be compromised even if the market would be liberalized on an MFN basis at last (Miroudot et.al, 2010) .Second, many services 
TABLE 8

Effect of “GATS+"“GATS=”and “GATS-” Commitment in RTAs on Trade in Services

\begin{tabular}{|c|c|c|c|c|}
\hline & Model 4 & Model4 & Medel5 & Medel5 \\
\hline $\ln \left(G D P_{i t}\right)$ & $\begin{array}{c}0.9014216^{* * *} \\
(0.2281555)\end{array}$ & $\begin{array}{c}0.5969049 * * * \\
(0.0692103)\end{array}$ & $\begin{array}{c}0.9007711^{* * * *} \\
(0.2282154)\end{array}$ & $\begin{array}{c}0.597924 * * * \\
(0.0692243)\end{array}$ \\
\hline $\ln \left(G D P_{j t}\right)$ & $\begin{array}{c}1.300031^{* * *} \\
(0.2284599)\end{array}$ & $\begin{array}{c}0.8699477 * * * \\
(0.0668117)\end{array}$ & $\begin{array}{c}1.299546 * * * \\
(0.22852)\end{array}$ & $\begin{array}{c}0.8686029 * * * \\
(0.0668375)\end{array}$ \\
\hline $\ln \left(D I S T_{i j}\right)$ & $\begin{array}{c}-1.056259 * * * \\
(0.0126577)\end{array}$ & $\begin{array}{c}-1.069466 * * * \\
(0.0127556)\end{array}$ & $\begin{array}{c}-1.054808^{* * *} \\
(0.0126382)\end{array}$ & $\begin{array}{c}-1.068205^{* * *} \\
(0.0127273)\end{array}$ \\
\hline$L A N G_{i j}$ & $\begin{array}{c}0.3808614^{* * *} \\
(0.0268986)\end{array}$ & $\begin{array}{c}0.3849278 * * * \\
(0.0274183)\end{array}$ & $\begin{array}{c}0.3853212^{* * *} \\
(0.0268614)\end{array}$ & $\begin{array}{c}0.3884489 * * * \\
(0.027381)\end{array}$ \\
\hline $\ln \left(M A^{G A T S+}{ }_{i t, j}\right)$ & $\begin{array}{c}0.0600679 * * * \\
(0.0108683)\end{array}$ & $\begin{array}{c}0.0501675 * * * \\
(0.0108615)\end{array}$ & & \\
\hline $\ln \left(M A^{G A T S=}{ }_{i t, j}\right)$ & $\begin{array}{c}0.3019005 * * \\
(0.1478224)\end{array}$ & $\begin{array}{c}0.403266^{* * *} \\
(0.1252887)\end{array}$ & & \\
\hline $\ln \left(M A^{G A T S-}{ }_{i t, j}\right)$ & $\begin{array}{l}-0.0114057 \\
(0.0145964)\end{array}$ & $\begin{array}{l}-0.0084347 \\
(0.014544)\end{array}$ & & \\
\hline $\ln \left(M A^{G A T S+}{ }_{j t, i}\right)$ & $\begin{array}{c}0.0241672 * * \\
(0.0106812)\end{array}$ & $\begin{array}{c}0.0209852^{* *} \\
(0.0107102)\end{array}$ & & \\
\hline $\ln \left(M A^{G A T S=}{ }_{j t, i}\right)$ & $\begin{array}{c}0.4352515^{* * *} \\
(0.1530347)\end{array}$ & $\begin{array}{c}0.2515564^{* * *} \\
(.1294167)\end{array}$ & & \\
\hline $\ln \left(M A_{j t, i}^{G A T S-}\right)$ & $\begin{array}{c}0.0137571 \\
(0.0146597)\end{array}$ & $\begin{array}{c}0.006415 \\
(0.0145929)\end{array}$ & & \\
\hline $\ln \left(N T_{i t, j}^{G A T S+}\right)$ & & & $\begin{array}{c}0.0639977 * * * \\
(0.0120686)\end{array}$ & $\begin{array}{c}0.0534987 * * * \\
(0.0120669)\end{array}$ \\
\hline $\ln \left(N T^{G A T S=}{ }_{i t, j}\right)$ & & & $\begin{array}{c}0.3220045 * * * \\
(0.1149216)\end{array}$ & $\begin{array}{c}0.3913433 * * * \\
(0.1007123)\end{array}$ \\
\hline $\ln \left(N T_{i t, j}^{\text {GATS- }}\right)$ & & & $\begin{array}{c}0.0007717 \\
(0.0144419)\end{array}$ & $\begin{array}{c}0.0026191 \\
(0.0143571)\end{array}$ \\
\hline $\ln \left(N T^{\text {GATS+ }}{ }_{j t, i}\right)$ & & & $\begin{array}{c}0.014508 \\
(0.0119556)\end{array}$ & $\begin{array}{l}0.0130882 \\
(0.119955)\end{array}$ \\
\hline $\ln \left(N T^{G A T S=}{ }_{j t, i}\right)$ & & & $\begin{array}{c}0.3962053 * * * \\
(0.1180575)\end{array}$ & $\begin{array}{c}0.2440655^{* *} \\
(0.1034092)\end{array}$ \\
\hline $\ln \left(N T_{j t, i}^{G A T S-}\right)$ & & & $\begin{array}{c}0.0048177 \\
(0.0145291)\end{array}$ & $\begin{array}{c}-0.0029639 \\
(0.0144354)\end{array}$ \\
\hline Observations & 13160 & 13160 & 13160 & 13160 \\
\hline F value & $F(907,12252)=79.62$ & $\mathrm{~F}(109,13050)=620.5$ & $F(907,12252)=79.58$ & $F(109,13050)=620.2$ \\
\hline Prob $>F$ & 0.0000 & 0.0000 & 0.0000 & 0.0000 \\
\hline R-squared & 0.8550 & 0.8383 & 0.8549 & 0.8382 \\
\hline $\begin{array}{l}\text { Adj R-squared } \\
\text { Fixed effect }\end{array}$ & 0.8442 & 0.8369 & 0.8441 & 0.8368 \\
\hline exporter-year $\left(\eta_{i, t}\right)$ & $\sqrt{ }$ & & $\sqrt{ }$ & \\
\hline importer-year $\left(\eta_{j, t}\right)$ & $\sqrt{ }$ & & $\sqrt{ }$ & \\
\hline $\operatorname{exporter}\left(\eta_{i}\right)$ & & $\sqrt{ }$ & & $\sqrt{ }$ \\
\hline $\operatorname{importer}\left(\eta_{j}\right)$ & & $\sqrt{ }$ & & $\sqrt{ }$ \\
\hline $\operatorname{year}\left(\eta_{t}\right)$ & & $\sqrt{ }$ & & $\sqrt{ }$ \\
\hline
\end{tabular}

NOTE: (1) Standard errors are in parentheses. The intercept is included but not reported. (2)*,**, *** indicates that the estimated coefficients are statistically significant at $10 \%, 5 \%$ and $1 \%$ respectively.

restrictions are embedded in regulatory regimes and place different regulatory regimes for suppliers from different economies would cause high enforcement cost. In fact, the liberalization basis of service sector is the increase of the competitiveness level of this service sector. Once the service sector has been opened to one member, government may be confident to open it to other economes, which means the propensity to de facto extend the preferences granted in RTAs to others is likely greater. The nature of the service 
regulation determined once one kind of service restriction had been removed for some economies then would not apply to others. Giving "GATS-minus" treatment to specific several objectives would create large administrative costs, so chances are that kind of negative commitments to some extent will just remain in the document instead of being put into practice.

\section{Conclusion}

The results of empirical research using the gravity equation either with time-varying exporter and importer fixed effect $\left(\eta_{i, t}\right.$ and $\left.\eta_{j, t}\right)$ or with the specific exporter and importer fixed effect $\left(\eta_{i}, \eta_{j}\right)$ and year fixed effect $\left(\eta_{t}\right)$ both indicate that belonging to a RTA can increase the bilateral service export between the trading-pairs significantly. It should be pointed that "only goods" RTAs and "service" RTAs can both have positive and significant effects on bilateral service trade, whose effect is larger cannot be determined precisely now. The effect of the "only goods" RTAs means service export can be promoted by raising member's bilateral goods trade. When taking the development level of the members into account, results show the trade-enhancing effects inducing from South-South "service" RTAs and North-South "service" RTAs are both significant and almost the same.

What's more, just as we have expected, almost all the "GATS-plus" and "GATSneutral" commitments either on market access or on national treatment made by tradingpairs with each other under the RTAs have significantly positive effects on bilateral service exports. Meanwhile the commitments of "GATS-minus" characteristic do not have significant negative effects on bilateral service exports because "GATS-minus" commitments can be neutralized to some extent by two main mechanisms under the RTAs: "liberal rule of origin" and "the non-party MFN provisions". The rationale to include these two preference erosion mechanism in the RTAs is to overcome the economic distortions and productivity loss caused by liberalization of service market on a preference basis and the large administrative and enforcement cost caused by using different regulatory regimes for different service supplier. 


\section{Reference}

Amélie Guillin (2013), 'Trade in Services and Regional Trade Agreements: Do Negotiations on Services have to be Specific? ', The World Economy, 36, 11, 1406-1423.

Anirudh Shingal (2010), 'How Much do Agreements Matter for Services Trade?', Paper for the ETSG Conference in Lausanne, September 9-11.

Arvind Subramanian and Shang-Jin Wei (2007), 'The WTO Promotes Trade, Strongly but Unevenly’, Journal of International Economics, 72(1), 151-175.

Carsten Fink and Martín Molinuevo (2007), 'Services Provisions in Regional Trade Agreements: Stumbling or Building Blocks for Multilateral Liberalization?' ,Paper presented at the Conference on Multilateralising Regionalism Sponsored and organized by WTO - HEI Co-organized by the Centre for Economic Policy Research (CEPR), 1012 September.

Daniel Mirza and Giuseppe Nicoletti (2004), 'What is so Special about Trade in Services?', Research Paper Series 2004/02, Leverhulme Centre for Research on Globalisation and Economic Policy, The University of Nottingham.

Fukunari Kimura and Hyun-Hoon Lee (2006), 'The Gravity Equation in International Trade in Services', Review of World Economies, 142(1), 92-121.

Innwon Park and Soonchan Park ( 2010), 'Regional Liberalization of Trade in Services’, Munich Personal RePEc Archive Paper 19758, University Library of Munich.

James E. Anderson and Eric van Wincoop (2003), 'Gravity with Gravitas: A Solution to the Border Puzzle’, American Economic Reviews, 93, 1,170-192.

Janet Ceglowski (2006), 'Does Gravity Matter in a Service Economy? ', Review of World Economics, 142(2), 307-329.

John Gilbert, Robert Scollay and Bijit Bora (2001), 'Assessing Regional Trading Arrangement in the Asia-Pacific', Policy Series No.15, United Nations Conference on Trade and Development, Geneva. 
Keith Walsh (2006), 'Trade in Services: Does Gravity Hold? A Gravity Model Approach to Estimating Barriers to Services Trade’, IIS Discussion Paper No. 183.

Leo A. Grünfeld and Andreas Moxnes (2003), 'The Intangible Globalization: Explaining the Patterns of International Trade in Services', Norwegian Institute of International Affairs 657.

Mario Marconini (2006) , 'Services in Regional Agreements between Latin American and Developed Counties’, United Nations Publication, ISSN printed version 1680-869x, ISSN electronic version 1680-872x, http://www.cepal.org/publicaciones/xml/4/26054/s71ci-12544i-p.pdf.

Marilyne Pereira Goncalve and Constantinos Stephanou (2007), 'Financial Services and Trade Agreements in Latin America and the Caribbean: An Overview', World Bank Policy Research Working Paper No. 4181. Available at: http://go.worldbank.org/48YUFADM70.

Martin Roy (2011) , 'Services Commitments in Preferential Trade Agreements: An Expanded Dataset’, WTO staff working paper ERSD-2011-18.

Martin Roy, Juan Marchetti and Hoe Lim (2006), 'Services Liberalization in the New Generation of Preferential Trade Agreements (PTAs): How Much Further than the GATS?’, Staff Working Paper No. ERSD-2006-07 (Geneva: World Trade Organization).

Nadine Behncke (2013), 'Assessing the Impact of European Integration on Sectoral Trade in Services?', FIW working paper No.109.

Pierre Latrille and Juneyoung Lee (2012), 'Service Rules in Regional Trade Agreements How Diverse and how Creative as Compared to the GATS Multilateral Rules?’ WTO staff working paper ERSD-2012-19.

Pierre Sauvé (2005), 'Adding Value at the Periphery: Elements of GATS+ Regional Agreements in Services', Paper prepared for the seminar Eyes Wide Shut? Beyond Market Access in North-South Regional Trade Arrangements, International Development Research Center, Ottawa. 
Richard Baldwin and Daria Taglioni (2006), 'Gravity for Dummies and Dummies for Gravity Equations’, NBER Working Paper 12516, Cambridge, MA.

Richard Baldwin and James Harrigan (2008), 'Zeroes, Quality and Space: Trade Theory and Trade Evidence,’ NBER, Working Paper 13214, March.

Richard Baldwin, Simon Evenett and Patrick Low(2007), 'Beyond Tariffs: Multilaterising Deeper RTA Commitments.' presented at WTO-HEI Conference on Multilateralising Regionalism, 10-12 September 2007,Conference Room II, WTO, Geneva, Switzerland.

Robert C.Feenstra (2004), 'Advanced International Trade: Theory and Evidence', Princeton University Press, Princeton, NJ.

Rudolf Adlung and Sébastien Miroudot (2012), 'Poison in the Wine? Tracing GATSminus Commitments in Regional Trade Agreements', WTO staff working paper ERSD2012-04, http://www.wto.org/english/res_e/reser_e/ersd201204_e.pdf

Rudolf Adlung and Hamid Mamdouh (2013), 'How to Design Trade Agreements in Services: Top down or Bottom up?', WTO staff working paper ERSD-2013-08, http://www.wto.org/english/res_e/reser_e/ersd201308_e.pdf.

Scott L.Baier and Jeffrey H.Bergstrand (2007), 'Do Free Trade Agreement Actually Increase Members’ International Trade? ', Journal of International Economics, 71, 1, 7295.

Sébastien Miroudot, Jehan Sauvage and Marie Sudreau (2010), 'Multilateralising Regionalism: How Preferential Are Services Commitments in Regional Trade Agreements’, OECD Trade Policy Papers No.106.

Sherry Stephenson (2005), 'Examining APEC’s Progress towards Reaching the Bogor Goals for Services Liberalization’ paper prepared for Pacific Economic Cooperation Council. 